\title{
SURVEY PUBLIC FINANCE MANAGEMENT (PFM) DI KABUPATEN FLORES TIMUR PROVINSI NUSA TENGGARA TIMUR
}

\author{
Thomas Ola Langoday \\ Universitas Widya Mandira, Kupang
}

\begin{abstract}
This study aims to see how far the implementation of the performance of Public Financial Management (PFM) in accordance with applicable standards and regulations. The survey shows that in general the performance of public financial management in East Flores Regency categorized as very good; from the nine areas that were analyzed, seven areas were very good in the category of regulatory framework; Planning and Budgeting: Cash Management: Procurement of Goods and Services; Debt and Public Investment: Asset Management, and the last External Audit and Oversight. One area is in both categories of Internal Control and the fields are at very low category of Accounting and Reporting. The result of this study recommends that the force placed on each SKPD or Bachelors degree in Accounting and Finance for financial management in a professional area. In the extreme, this study recommends that the chief of Budget, Accounting, Accounting and Reporting, and Verification at the Department of Finance and Asset Areas on each District/City should be headed by a person with qualifications or Bachelors degree in Accounting and Finance.
\end{abstract}

Keywords: performance, public financial management, degree in accounting.

\section{A. LATAR BELAKANG}

Kebijakan otonomi daerah dan desentralisasi fiskal di Indonesia telah memberikan kewenangan yang lebih besar kepada pemerintah daerah dalam proses perencanaan dan implementasi pembangunan daerah. Pengalihan kewenangan ini disertai dengan pengalihan sumber keuangan dalam bentuk dana perimbangan dari pemerintah pusat kepada pemerintah daerah. Kewenangan pemerintah daerah yang semakin besar ini menuntut proses perencanaan dan penganggaran yang lebih baik untuk meningkatkan pertumbuhan ekonomi dan pelayanan publik daerah.

Proses perencanaan dan penganggaran pembangunan daerah yang baik, tidaklah serta merta membawa kemanfaatan optimal bagi pembangunan daerah, jika kapasitas manajemen sumberdaya pembangunan termasuk keuangan dan aset-aset daerah belum menunjang. Demikian juga halnya dengan pengawasan internal dan eksternal sangat penting sebagai jaminan adanya akuntabilitas dari manajemen pembangunan daerah.

Untuk menjamin tertib dan ketaatan proses, prosedure dan tata cara dari manegemen pembangunan daerah mulai dari perencanaan dan penganggaran, implementasi sampai dengan pengawasannya, telah ditetapkan peraturan perundangan, baik berupa undang-undang, peraturan 
pemerintah, peraturan menteri bahkan sampai peraturan daerah dan keputusan kepala daerah. Ketertiban dan ketaatan proses, prosedure dan tata cara dari manajemen pembangunan daerah dimaksud, secara konseptual didefinisikan dalam penelitian ini sebagai Kapasitas Pengelolaan Keuangan Publik (Public Financial Management Capacity) di daerah. Sudah menjadi pengetahuan umum bahwa kinerja pembangunan daerah belum optimal dalam masa otonomi daerah dan desentralisasi fiskal ini. Oleh karenanya Kapasitas Pengelolaan Keuangan Publik (Public Financial Management Capacity) di daerah sebagai salah satu aspek penting dalam optimalisasi manfaat pembangunan daerah perlu dievaluasi kinerjanya.

Bidang-bidang otonomi daerah dan desentralisasi fiskal di Indonesia dalam konteks study Public Financial Management (PFM) Capasity; paling tidak meliputi sembilan (9) bidang yaitu: 1) kerangka peraturan perundangan daerah; 2) perencanaan dan penganggaran; 3) pengelolaan kas; 4) pengadaan barang dan jasa; 5) akuntansi dan pelaporan; 6) pengawasan internal; 7) hutang dan investasi publik; 8) pengelolaan aset, dan 9) pengawasan eksternal. Implementasi kesembilan bidang tersebut diatur lewat sejumlah peraturan perundangan dalam bentuk; Undang-undang, Peraturan Pemerintah, Peraturan Menteri, dan peraturan turunanan lainnya. Tujuan study PFM Capacity di Kabupaten Flores Timur adalah untuk mendapat gambaran komprehensif tentang tingkat kinerja implementasi kesembilan bidang PFM dimaksud dengan standar pada peraturan perundangan yang memanyunginya. Kegunaan study adalah untuk meningkatkan kapasitas pengelolaan keuangan daerah dalam rangka mengoptimalkan manfaat pembangunan daerah.

\section{B. METODE PENELITIAN DAN ANALISIS DATA}

\section{Metode dan Teknik Pengumpulan Data}

Metode dan teknik pegumpulan data dan informasi yang digunakan adalah secara survey melalui wawancara dan orientasi lapangan. Untuk itu target responden yang diperkirakan sebagai sumber informasi ditetapkan secara purposive dengan mempertimbangkan tugas pokok dan fungsi berdasarkan peraturan perundang-perundangan yang berlaku terkait dan relevan dengan kajian yang dilaksanakan. Responden yang dimaksud meliputi pimpinan wilayah dalam hal ini sekretaris daerah, badan perencanaan pembangunan daerah/bappeda, pimpinan satuan kerja perangkat daerah, bagian keuangan/dinas PPKAD, DPRD, Inspektorat Daerah.

Selain itu juga dilakukan dokumentasi terhadap berbagai dokumen dan pelaporan yang berkenaan dengan penelitian ini.

\section{Indikator}

Sejalan dengan tujuan pengkajian yang akan dicapai, terdapat 9 (sembilan) bidang strategis yang merupakan variabel utama dalam hubungannya dengan pengelolaan keuangan publik, yakni: 1) kerangka peraturan perundangan daerah; 2) perencanaan dan penganggaran; 3) manajemen kas/penatausahan; 4) pengadaan barang dan jasa; 5) akuntansi dan pelaporan; 6) pengawasan intern; 7) hutang dan investasi publik; 8) pengelolaan aset, dan 9) pengawasan eksternal. 
Selanjutnya dari kesembilan bidang strategis di atas, indikator yang menjadi fokus analisis sebanyak 56 buah dengan 26 outcomes. Untuk lebih jelas, disajikan pada Tabel 1.

Tabel 1. Jumlah Indikator dan Skor Maksimum dari setiap Sasaran/Hasil dan Bidang Strategis

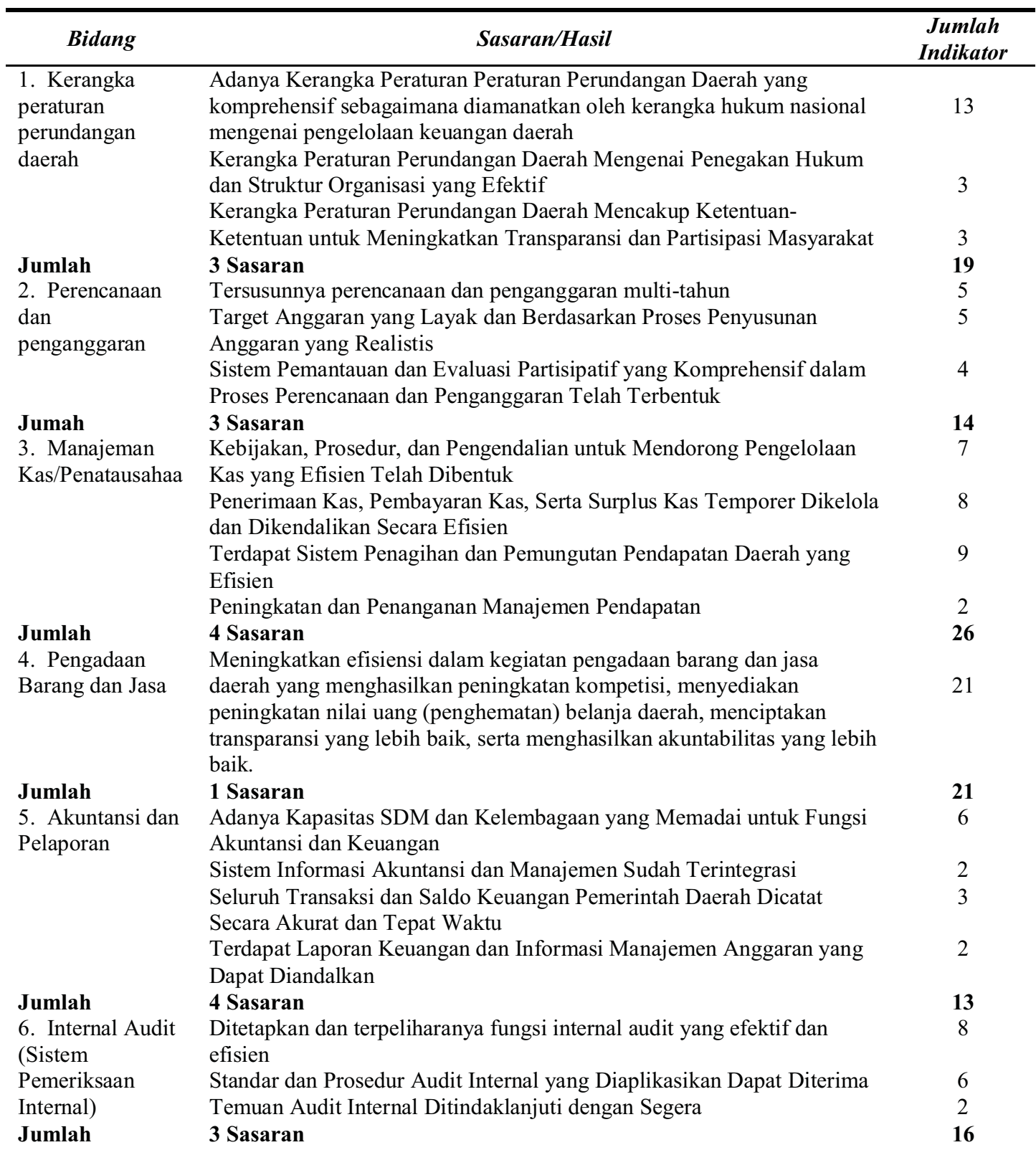




\begin{tabular}{llc}
\hline 7. Hutang dan & Kebijakan, Prosedur, serta Pengendalian dan Pinjaman Investasi Daerah & 5 \\
Investasi Publik & yang Memperhitungkan Resiko Telah Ditetapkan dan Dilaksanakan \\
& $\begin{array}{l}\text { Kebijakan, Prosedur dan Pengelolaan Penerimaan Hibah telah ditetapkan } \\
\text { dan dilaksanakan }\end{array}$ & 4 \\
Jumlah & 2 Sasaran & $\mathbf{9}$ \\
8. Pengelolaan & $\begin{array}{l}\text { Terdapat kebijakan yang mengatur penggunaan dan pemanfaatan aset } \\
\text { Aset }\end{array}$ & 5 \\
& $\begin{array}{l}\text { daerah yang mendukung tertib pengelolaan aset daerah } \\
\text { Kebijakan dan prosedur pemeliharaan asset dilakukan dan terintegrasi } \\
\text { dengan proses perencanaan daerah untuk memastikan kondisi aset selalu }\end{array}$ & 3 \\
& $\begin{array}{l}\text { siap digunakan } \\
\text { Terdapat kebijakan, sistem dan prosedur pencatatan, perolehan, }\end{array}$ & 10 \\
& $\begin{array}{l}\text { penilaian, pemindahtangan dan penghapusan dan pelaporan barang } \\
\text { daerah yang efektif }\end{array}$ & \\
Jumlah & 3 Sasaran \\
9. Pengawasan & Audit Eksternal Rutin Menjamin Efektivitas dan Akuntabilitas \\
Ekstern & Pemerintah Daerah & $\mathbf{1 8}$ \\
& Adanya pemantau independen yang efektif terhadap manajemen & 5 \\
Jumlah & keuangan daerah & 3 \\
Jumlah & 2 Sasaran \\
Seluruhnya & 25 Sasaran/hasil & $\mathbf{8}$ \\
\hline
\end{tabular}

Sumber:

\section{Sistem Skoring}

Keseluruhan data dan informasi yang terkumpul selanjutnya ditabulasi dan diklasifikasi menurut karakteristik dan variabel yang bersesuaian. Penerapan analisis skor pada masingmasing daerah Kabupaten/Kota di NTT adalah sebagai berikut:

a. Setiap hasil memiliki indikator yang menunjukkan pencapaian outcome tersebut

b. Untuk setiap indikator terdapat 2 kemungkinan jawaban, YA jika indikator tersebut telah terpenuhi atau TIDAK jika sebaliknya

c. Setiap jawaban YA bernilai 1 dan TIDAK bernilai 0

d. Skor diakumulasikan untuk setiap hasil dan Bidang strategis

e. Setiap hasil dan Bidang Strategis memiliki skor maksimal sesuai dengan jumlah indikator yang berada dibawahnya

f. Pencapaian skor setiap hasil dan Bidang Strategis kemudian dihitung persentasenya terhadap skor maksimal yang seharusnya dicapai.

\section{Kriteria Level Kinerja Pengelolaan Keuangan Publik}

Hasil perhitungan persentase pencapaian skor setiap outcomes (hasil) dan Bidang Strategis akan berada pada kisaran $0.00 \%$ sampai $100.00 \%$, yang dibagi menjadi 5 (lima) kategori level kinerja pengelolaan keuangan publik seperti tampak pada Tabel 2. 
Tabel 2. Kriteria Level Kinerja Pengelolaan Keuangan Publik

\begin{tabular}{c|cc}
\hline NO & BOBOT (\%) & LEVEL KINERJA \\
\hline 1 & $80-100$ & Exellent/Fully Acceptable \\
2 & $60-79$ & Very Good/Substantially Acceptable \\
3 & $40-59$ & Good/Fairly Acceptable \\
4 & $20-39$ & Moderate/Parttially Acceptable \\
5 & $00-19$ & Poor/Not Acceptable \\
\hline
\end{tabular}

Sumber:

\section{HASIL DAN PEMBAHASAN}

Survey ini menganalisis sembilan bidang utama pengelolaan keuangan publik yang ada pada pemerintah Kabupaten Flores Timur. Adapun sembilan bidang tersebut adalah: 1) Kerangka Peraturan Perundangan Daerah; 2) Perencanaan dan Penganggaran; 3) Pengelolaan Kas; 4) Pengadaan Barang dan Jasa; 5) Akuntansi dan Pelaporan; 6) Pengawasan Intern; 7) Hutang dan Investasi Publik; 8) Pengelolaan Aset; dan 9) Audit dan Pengawasan Eksternal. Dari sembilan bidang yang ada, hasil analisis menunjukkan bahwa tidak ada satupun bidang yang mendapatkan skor sempurna/exellent dengan capaian skor antara 80\%-100\%. Capaian skor tertinggi adalah bidang hutang dan investasi publik yaitu sebesar $78 \%$ dan capaian skor terendah adalah bidang akuntansi dan pelaporan yaitu sebesar $31 \%$.

Secara keseluruhan, dapat dikatakan bahwa pengelolaan keuangan publik di Kabupaten Flores Timur dikategorikan sangat baik. Hal ini dapat dilihat dari total capaian skor kesembilan bidang yang dianalisis yang mencapai $66.30 \%$. Namun demikian ada bidang yang perolehan skornya di atas $66.30 \%$ dan ada pula capaian skor bidang tertentu di bawah $66.30 \%$.

Tabel 3. Total Skor Sembilan Bidang Analisis PFM di Kabupaten Flores Timur

\begin{tabular}{lcc}
\hline \multicolumn{1}{c}{ AREA } & SCORE & $\%$ \\
Bidang 1: kerangka peraturan perundangan daerah & 12 & $63 \%$ \\
Bidang 2: perencanaan dan penganggaran & 9 & $64 \%$ \\
Bidang 3: pengelolaan kas & 18 & $69 \%$ \\
Bidang 4: pengadaan & 15 & $71 \%$ \\
Bidang 5: akuntansi dan pelaporan & 4 & $31 \%$ \\
Bidang 6: pengawasan intern & 9 & $56 \%$ \\
Bidang 7: hutang dan investasi publik & 7 & $78 \%$ \\
Bidang 8: pengelolaan asset & 13 & $72 \%$ \\
Bidang 9: audit dan pengawasan eksternal & 6 & $75 \%$ \\
TOTAL STATEMENTS & $\mathbf{9 5 . 5}$ & $\mathbf{6 6 . 3 0 \%}$ \\
\hline
\end{tabular}

Sumber: Pengolahan data lapangan, 2010 


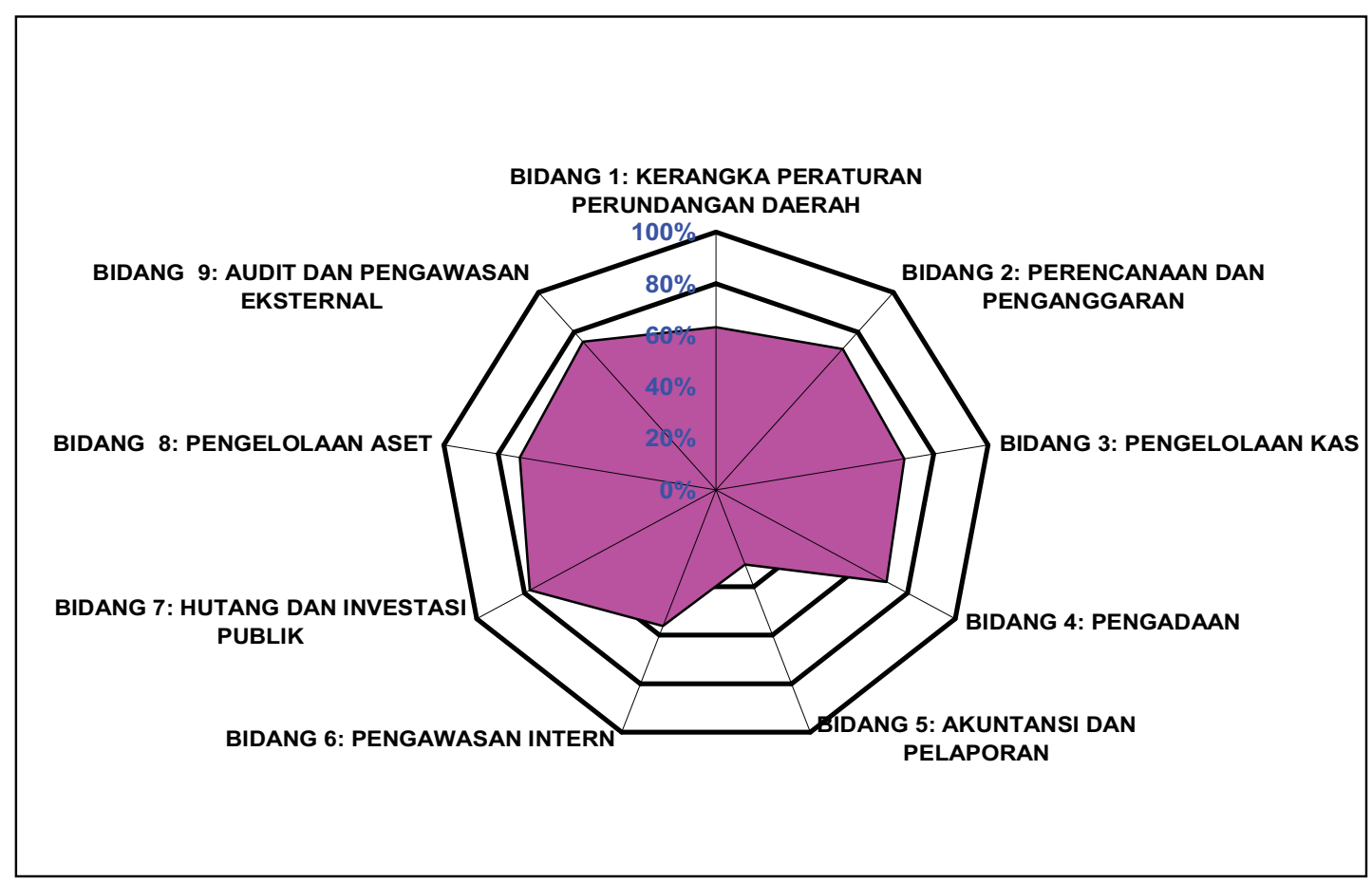

Gambar 1. Public Finance Management Capacity Assessment Kabupaten Flores Timur

Adapun tujuan strategis, sasaran dan indikator masing-masing bidang yang dinalisis beserta capaian skornya per bidang dapat dijelaskan seperti berikut.

\section{Bidang Kerangka Peraturan Perundangan Daerah}

Sasaran umum bidang kerangka peraturan perundangan daerah adalah adanya kerangka peraturan perundangan daerah yang komprehensif sebagaimana diamanatkan oleh kerangka hukum nasional mengenai pengelolaan keuangan daerah. Secara keseluruhan total skor bidang kerangka peraturan perundangan daerah mencapai $63,20 \%$ dan berada pada kategori sangat baik. Hal ini ditunjukkan dengan adanya capaian skor sasaran kerangka peraturan perundangan daerah yang komprehensif sebagaimana diamanatkan oleh kerangka hukum nasional mengenai pengelolaan keuangan daerah. Nilai capaian skor untuk sasaran ini sebesar 69,20\%. Kendati belum banyak peraturan daerah namun pelaksanaan pekerjaan selalu mengacu kepada peraturan atau perundang-undangan yang lebih tinggi. Hasil diagnosis bidang kerangka peraturan perundangan daerah dapat dilihat pada Tabel 4. 
Tabel 4.Total Capaian Skor Bidang Kerangka Peraturan Perundangan di Kabupaten Flores Timur

\begin{tabular}{|c|c|c|c|}
\hline Outcomes & $\begin{array}{c}\text { Total } \\
\text { achievable } \\
\text { score }\end{array}$ & $\begin{array}{l}\text { Total } \\
\text { achieved } \\
\text { score }\end{array}$ & $\begin{array}{c}\text { Area } \\
\text { grade } \\
\%\end{array}$ \\
\hline $\begin{array}{l}\text { Adanya Kerangka Peraturan Perundangan Daerah } \\
\text { yang komprehensif sebagaimana diamanatkan } \\
\text { oleh kerangka hukum nasional mengenai } \\
\text { pengelolaan keuangan daerah }\end{array}$ & 13 & 9 & $69.2 \%$ \\
\hline $\begin{array}{l}\text { Kerangka Peraturan Perundangan Daerah } \\
\text { Mengenai Penegakan Hukum dan Struktur } \\
\text { Organisasi yang Efektif }\end{array}$ & 3 & 3 & $100.0 \%$ \\
\hline $\begin{array}{l}\text { Kerangka Peraturan Perundangan Daerah } \\
\text { Mencakup Ketentuan-Ketentuan untuk } \\
\text { Meningkatkan Transparansi dan Partisipasi } \\
\text { Masyarakat }\end{array}$ & 3 & 0 & $0.0 \%$ \\
\hline TOTAL & 19 & 12 & $63.2 \%$ \\
\hline
\end{tabular}

Capaian skor yang tinggi didukung dengan adanya kerangka peraturan perundangan daerah mengenai penegakan hukum dan struktur organisasi yang efektif. Namun demikian, sampai sejauh ini belum ada kerangka peraturan perundangan daerah mencakup ketentuan-ketentuan untuk meningkatkan transparansi dan partisipasi masyarakat. Hal ini terjadi karena adanya semacam anggapan yang keliru bahwa tanpa dibuat peraturan perundangan yang terkait dengan transparansi dan partisipasi, masyarakat akan mengetahui dan dengan sendirinya berpartisipasi dalam proses penganggaran seperti mengikuti kegiatan musrenbangdus dan musrenbangdes.

Capaian skor kerangka peraturan perundangan daerah yang sangat baik didukung pula oleh adanya peraturan bupati no. 03 Tahun 2010 tanggal 09 Januari 2010 tentang standar biaya. Peraturan bupati tentang standar biaya ini penting karena menjadi dasar untuk penetapan biaya pengadaan barang dan jasa pada tahun berjalan. Selain standar biaya, ada pula surat keputusan bupati tentang analisa standar belanja; hal ini tertuang dalam surat keputusan bupati nomor 188 tahun 2009 tanggal 16 Oktober 2009. Analisa standar belanja ini menjadi acuan dalam penetapan plafon belanja barang dan jasa pada tiap tahun anggaran.

Pada sisi lain, beberapa kerangka peraturan perundangan daerah yang komprehensif sebagaimana yang diamanatkan oleh kerangka hukum nasional mengenai pengelolaan keuangan daerah yang belum dilaksanakan di antaranya adalah penetapan peraturan perundangan daerah mengenai APBD tidak tepat waktu di mana untuk APBD tahun 2009 seharusnya ditetapkan sebelum tanggal 1 Januari tahun 2009, dalam prakteknya ditetapkan pada tanggal 23 Pebruari 2009. keterlambatan penetapan APBD ini karena keterlambatan pembahasan pada tingkat SKPD. Kendati demikian, APBD tahun 2010 ditetapkan tepat waktu yaitu sebelum tanggal 1 Januari 2010, tepatnya pada tanggal 30 Desember 2009. Selain itu, belum ada peraturan kepala daerah tentang kebijakan akuntansi pemerintah daerah; untuk hal tersebut pelaksanaan keakuntansian 
didasarkan pada peraturan yang lebih tinggi seperti peraturan atau keputusan menteri, atau peraturan pemerintah. Sampai sejauh ini penanaman modal daerah belum diatur dalam peraturan perundangan daerah. Peraturan perundangan daerah lainnya yang belum ada sampai dengan penelitian ini dilaksanakan adalah tentang badan layanan umum daerah (BLUD).

Di kabupaten Flores Timur, kerangka peraturan perundangan daerah mengenai penegakkan hukum dan struktur organisasi yang efektif telah dilaksanakan dengan baik. Bahkan Kabupaten Flores Timur terkenal sebagai kabupaten yang memelopori pelaksanaan PP 41/2007 dan PP 38/ 2007 sebelum ada petunjuk teknis yang mengikutinya. Sementara kabupaten/kota lain di NTT melaksanakannya setelah ada petunjuk teknis lebih lanjut.

Salah satu kelemahan terbesar di Kabupaten Flores Timur yang berkaitan dengan kerangka perundangan perencanaan dan pembangunan adalah belum ada kerangka peraturan perundangan daerah yang mencakup ketentuan-ketentuan untuk meningkatkan transparansi dan partisipasi masyarakat. Hal ini jelas terlihat dari belum adanya peraturan perundangan daerah mengenai transparansi dan partisipasi serta rendahnya akses masyarakat terhadap sidang-sidang DPRD mengenai APBD. Hal ini ditunjukkan dengan tidak adanya bukti seperti daftar hadir yang menunjukkan bahwa masyarakat mengikuti sidang mengenai APBD di DPRD.

Oleh karena itu, hal-hal yang belum ada dan belum dilaksanakan tersebut diharapkan dapat diadakan dan dilaksanakan pada waktu-waktu yang akan datang guna tercapainya sasaran seluruh bidang strategis dalam kerangka peraturan perundangan tentang perencanaan dan penganggaran.

\section{Bidang Perencanaan dan Penganggaran}

Secara umum, sasaran bidang strategis perencanaan dan penganggaran adalah tersusunnya perencanaan dan penganggaran yang tepat dan terhubung dengan perencanaan daerah. Capaian total skor bidang perencanaan dan penganggaran di Kabupaten Flores Timur sebesar 64.30\% dan berada pada kategori sangat baik. Hasil diagnosis bidang perencanaan dan penganggaran dapat dilihat pada Tabel 5.

Tabel 5. Total Capaian Skor Bidang Perencanaan dan Penganggaran di Kabupaten Flores Timur

\begin{tabular}{|c|c|c|c|}
\hline Outcomes & $\begin{array}{l}\text { Total Achievable } \\
\text { Score }\end{array}$ & $\begin{array}{l}\text { Total Achieved } \\
\text { Score }\end{array}$ & $\begin{array}{l}\text { Area } \\
\text { Grade }\end{array}$ \\
\hline $\begin{array}{l}\text { Tersusunnya perencanaan dan } \\
\text { penganggaran multi-tahun }\end{array}$ & 5 & 4 & $80.0 \%$ \\
\hline $\begin{array}{l}\text { Target Anggaran yang Layak dan } \\
\text { Berdasarkan Proses Penyusunan } \\
\text { Anggaran yang Realistis }\end{array}$ & 5 & 4 & $80.0 \%$ \\
\hline $\begin{array}{l}\text { Sistem Pemantauan dan Evaluasi } \\
\text { Partisipatif yang Komprehensif } \\
\text { dalam Proses Perencanaan dan } \\
\text { Penganggaran Telah Terbentuk }\end{array}$ & 4 & 1 & $25.0 \%$ \\
\hline TOTAL & 14 & 9 & $64.3 \%$ \\
\hline
\end{tabular}

Sumber: Pengolahan Data Lapangan, 2010 
Ada tiga sasaran khusus yang hendak dicapai dalam bidang perencanaan dan penganggaran yaitu pertama tersusunnya perencanaan dan penganggaran multi-tahun. Perencanaan dan penganggaran multi tahun berarti rencana dan anggaran dibuat dalam beberapa tahun anggaran yang tersambung satu dengan lainnya baik sasaran, program dan penganggaran guna mencapai tujuan tertentu dalam jangka menengah. Perencanaan dan penganggaran multi tahun tampak dalam rencana pembangunan jangka menengah daerah (RPJMD). Hasil analisis menunjukkan bahwa capaian sasaran ini sebesar $80 \%$. Aspek yang belum dicapai dalam sasaran ini adalah bahwa dalam anggaran satuan kerja terdapat skor-skor yang terukur tetapi setelah ditelusuri hampir semuanya belum merujuk pada strategi. Oleh karena itu diharapkan pada waktu yang akan datang, penyusunan skor yang terukur harus merujuk pada strategi yang telah ditetapkan.

Tidak dapat dipungkiri bahwa penetapan terget anggaran di Kabupaten Flores Timur sudah dapat dilakukan secara layak dan berdasarkan proses penyusunan anggaran yang realistik. Kendati perbedaan antara total anggaran belanja tahun 2008 dengan realisasi APBD tahun 2007 mencapai $17.43 \%$, namun indikator lainnya tercapai dengan baik seperti tidak pernah terjadi defisit realisasi anggaran selama tiga tahun terakhir; demikian pula perbedaan antara APBD induk dan ABPD-P untuk kelompok belanja langsung pada tahun 2008 tidak mencapai 10\% yaitu hanya mencapai $9 \%$.

Namun demikian, pada sisi lainnya capaian skor sistem pemantauan dan evaluasi partisipatif yang komprehensip dalam proses perencanaan dan penganggaran belum terbentuk dan dilaksanakan dengan baik. Hal ini ditunjukkan dengan capaian skor yang hanya $25,0 \%$. Aspekaspek yang belum dilaksanakan terkait dengan sasaran ini adalah bahwa belum terdapatnya proses evaluasi atas RKA-SKPD dalam hal kesesuaian dengan KUA dan PPAS. Aspek lain yang menjadi kendala tercapainya sasaran ini adalah masyarakat masih sulit mengakses dokumen perencanaan dan penganggaran. Sebagai catatan, para akademisi dan peneliti saja sangat sulit mendapatkan dokumen perencanaan dan penganggaran, apalagi masyarakat luas atau kelompok masyarakat lainnya. Aspek yang tidak kalah penting yang ikut menghambat tercapainya sasaran ini adalah masyarakat belum dilibatkan dalam pemantauan dan evaluasi kegiatan yang dilaksanakan oleh SKPD di Kabupaten Flores Timur. Pengalaman selama ini menunjukkan bahwa pemantauan dan evaluasi kegiatan hanya terbatas pada institusi yang berwewenang seperti anggota DPRD atau inspektorat daerah. Aspek yang mendukung pencapaian sasaran ini di Kabupaten Flores Timur adalah bahwa proses perencanaan dan penganggaran telah mencakup komponen partisipatif, yang ditunjukkan dengan keterlibatan masyarakat dalam berbagai tingkatan musrenbangda, kendati belum ada aturan tentang partisipasi masyarakat.

\section{Bidang Pengelolaan Kas}

Tujuan strategis bidang pengelolaan kas adalah penerapan praktik-praktik manajemen kas yang efektif guna memastikan pengelolaan dana yang efisien untuk pelayanan. Capaian total skor bidang pengelolaan kas di Kabupaten Flores Timur sebesar $69.20 \%$ dan berada pada kategori sangat baik.

Untuk mencapai tujuan strategis tersebut maka ada empat sasaran yang hendak dicapai. Ada dua sasaran yang telah dilaksanakan secara baik oleh pemerintah Kabupaten Flores Timur yaitu pertama: telah dibentuk kebijakan, prosedur, dan pengendalian untuk mendorong pengelolaan 
kas yang efisien; dan kedua peningkatan dan penanganan manajemen pendapatan. Salah satu bentuk kebijakan, prosedur dan pengendalian untuk mendorong pengelolaan kas yang efisien adalah dengan ditetapkan prosedur membuka rekening bank dengan surat keputusan bupati no. 01 tahun 2009 tanggal 26 Pebruasi 2009. Sasaran ketiga juga telah dilaksanakan dengan baik dengan capaian skor mencapai $87.50 \%$ yaitu penerimaan kas, pembayaran kas, serta surplus kas temporer dikelola dan dikendalikan secara efisien. Ada kendala dalam pencapaian sasaran ini yaitu ada rancangan peraturan mengenai pajak dan retribusi daerah yang ditolak oleh pemerintah; alasannya bahwa perda yang diajukan lebih bersifat pungutan dari pada pelayanan di mana tidak dipersiapkan sarana dan prasarana seperti penyediaan tempat penjualan yang layak bagi para wajib pajak dan retribusi. Hasil diagnosis bidang pengelolaan kas dapat dilihat pada Tabel 6 .

Tabel 6. Total Capaian Skor Bidang Pengelolaan Kas di Kabupaten Flores Timur

\begin{tabular}{|c|c|c|c|}
\hline Outcomes & $\begin{array}{c}\text { Total } \\
\text { Achievable } \\
\text { Score }\end{array}$ & $\begin{array}{l}\text { Total } \\
\text { Achieved } \\
\text { Score }\end{array}$ & $\begin{array}{l}\text { Area } \\
\text { Grade }\end{array}$ \\
\hline $\begin{array}{l}\text { Kebijakan, Prosedur, dan Pengendalian } \\
\text { untuk Mendorong Pengelolaan Kas yang } \\
\text { Efisien Telah Dibentuk }\end{array}$ & 7 & 7 & $100.0 \%$ \\
\hline $\begin{array}{l}\text { Penerimaan Kas, Pembayaran Kas, } \\
\text { Serta Surplus Kas Temporer Dikelola } \\
\text { dan Dikendalikan Secara Efisien }\end{array}$ & 8 & 7 & $87.5 \%$ \\
\hline $\begin{array}{l}\text { Terdapat Sistem Penagihan dan } \\
\text { Pemungutan Pendapatan Daerah yang } \\
\text { Efisien }\end{array}$ & 9 & 4 & $44.4 \%$ \\
\hline $\begin{array}{l}\text { Peningkatan dan Penanganan } \\
\text { Manajemen Pendapatan }\end{array}$ & 2 & 2 & $100.0 \%$ \\
\hline TOTAL & 26 & 18 & $69.2 \%$ \\
\hline
\end{tabular}

Sumber: Pengolahan Data Lapangan, 2010

Ada satu sasaran yang belum dilaksanakan secara baik yaitu sistem penagihan dan pemungutan pendapatan daerah belum dilaksanakan secara efisien, dimana total skor untuk sasaran tersebut mencapai $44.40 \%$. Aspek yang menyebabkan rendahnya pencapaian sasaran ini antara lain adalah: adanya rancangan peraturan mengenai pajak dan retribusi daerah yang ditolak oleh pemerintah, dalam hal ini kementerian dalam negeri dan kementerian keuangan. Aspek lainnya adalah sistem penagihan dan pemungutan yang belum terintegrasi; hal ini terjadi karena unit pengelola teknis daerah (UPTD) yang ada pada setiap SKPD tersebar luas dan berjauhan satu dengan lainnya. Selain itu belum tersedianya layanan untuk menanggapi pertanyaan para pembayar pajak. Disini dibutuhkan badan layanan tersendiri sehingga pelayanan kepada wajib pajak lebih optimal. Kendati ada peraturan bahwa kelalaian membayar pajak dikenakan denda, tetapi sampai sejauh ini belum ada sanksi tegas yang dikenakan kepada para penunggak utang pajak. Ada kesan bahwa lebih baik para penunggak utang pajak terlambat membayar dari pada tidak sama sekali. Ini memberi kesan bahwa tidak ada sanksi tegas yang diberikan kepada para penunggak utang pajak. Aspek yang ikut mendorong tidak tercapainya sasaran ini adalah 
bahwa bagian keuangan belum melakukan rekonsiliasi harian terhadap rekening bank yang terkait dengan pendapatan.

\section{Bidang Pengadaan}

Tujuan strategis bidang pengadaan barang dan jasa adalah tersusunnya prosedur dan praktekpraktek pengadaan barang dan jasa yang mendukung kepada good governance. Hasil analisis menunjukkan bahwa total skor untuk bidang pengadaan barang dan jasa mencapai $71.40 \%$ dan berada pada kategori sangat baik. Untuk mencapai tujuan strategis tersebut maka sasaran yang hendak dicapai adalah meningkatkan efisiensi dalam kegiatan pengadaan barang dan jasa daerah yang menghasilkan peningkatan kompetisi, menyediakan peningkatan nilai uang (penghematan) belanja daerah, menciptakan transparansi yang lebih baik, serta menghasilkan akuntabilitas yang lebih baik. Hasil diagnosis bidang pengadaan barang dan jasa dapat dilihat pada Tebel 7.

Tabel 7. Total Capaian Skor Bidang Pengadaan Barang dan Jasa di Kabupaten Flores Timur

\begin{tabular}{lccc}
\hline \multicolumn{1}{c}{ Outcomes } & $\begin{array}{c}\text { Total } \\
\text { Achievable } \\
\text { Score }\end{array}$ & $\begin{array}{c}\text { Total } \\
\text { Achieved } \\
\text { Score }\end{array}$ & $\begin{array}{c}\text { Area } \\
\text { Grade }\end{array}$ \\
$\begin{array}{l}\text { Meningkatkan efisiensi dalam kegiatan } \\
\text { pengadaan barang dan jasa daerah yang }\end{array}$ & 21 & 15 & $\mathbf{7 1 . 4 \%}$ \\
$\begin{array}{l}\text { menghasilkan peningkatan kompetisi, } \\
\text { menyediakan peningkatan nilai uang } \\
\text { (penghematan) belanja daerah, }\end{array}$ & & & \\
$\begin{array}{l}\text { menciptakan transparansi yang lebih baik, } \\
\text { serta menghasilkan akuntabilitas yang }\end{array}$ & & & \\
lebih baik. & $\mathbf{2 1}$ & $\mathbf{1 5}$ & $\mathbf{7 1 . 4 \%}$ \\
\hline \multicolumn{1}{c}{ TOTAL } & & &
\end{tabular}

Sumber: Pengolahan Data Lapangan, 2010

Hasil analisis menunjukkan bahwa capain skor untuk sasaran ini sangat baik yaitu mencapai 71.40\%. Capaian skor yang sangat baik ini karena baik panitia pengadaan barang dan jasa maupun pengguna dan penyedia barang dan jasa sangat hati-hati dalam menerapkan aturan yang tercantum dalam peraturan pemerintah khususnya Kepres 80/2003.

\section{Bidang Akuntansi dan Pelaporan}

Tujuan strategis bidang akuntansi dan pelaporan adalah ditetapkannya sistem akuntansi yang menjamin terlaksananya akuntansi yang tepat atas seluruh transaksi keuangan dan menghasilkan laporan keuangan eksternal dan internal yang dapat diandalkan, wajar, dan tepat waktu. Hasil analisis menunjukkan bahwa total skor bidang akuntansi dan pelaporan di Kabupaten Flores Timur tergolong sedang/moderat yaitu hanya mencapai $30.80 \%$ dan merupakan skor yang terrendah dari sembilan bidang yang dianalisis. Hasil diagnosis bidang akuntansi dan pelaporan ditunjukkan pada Tabel 8 . 
Tabel 8. Total Capaian Skor Bidang Akuntansi dan Pelaporan di Kabupaten Flores Timur

\begin{tabular}{lccc}
\hline \multicolumn{1}{c}{ Outcomes } & $\begin{array}{c}\text { Total Achievable } \\
\text { Score }\end{array}$ & $\begin{array}{c}\text { Total } \\
\text { Achieved } \\
\text { Score }\end{array}$ & $\begin{array}{c}\text { Area } \\
\text { Grade }\end{array}$ \\
$\begin{array}{l}\text { Adanya Kapasitas SDM dan } \\
\text { Kelembagaan yang Memadai untuk }\end{array}$ & 6 & 3 & $\mathbf{5 0 . 0 \%}$ \\
$\begin{array}{l}\text { Fungsi Akuntansi dan Keuangan } \\
\text { Sistem Informasi Akuntansi dan }\end{array}$ & 2 & 1 & $\mathbf{5 0 . 0 \%}$ \\
$\begin{array}{l}\text { Manajemen Sudah Terintegrasi } \\
\text { Seluruh Transaksi dan Saldo Keuangan }\end{array}$ & 3 & 2 & $\mathbf{6 6 . 7 \%}$ \\
$\begin{array}{l}\text { Pemerintah Daerah Dicatat Secara } \\
\text { Akurat dan Tepat Waktu } \\
\text { Terdapat Laporan Keuangan dan } \\
\text { Informasi Manajemen Anggaran yang }\end{array}$ & 2 & 1 & $\mathbf{5 0 . 0 \%}$ \\
$\begin{array}{l}\text { Dapat Diandalkan } \\
\text { TOTAL }\end{array}$ & 13 & $\mathbf{4}$ & $\mathbf{3 0 . 8 \%}$ \\
\hline
\end{tabular}

Sumber: Pengolahan Data Lapangan, 2010

Untuk mencapai tujuan strategis tersebut maka ada empat sasaran yang hendak dicapai. Sasaran pertama adalah adanya kapasitas SDM dan kelembagaan yang memadai untuk fungsi akuntansi dan keuangan. Capaian skor untuk sasaran ini hanya 33.30\%. Aspek yang menghambat capaian sasaran ini adalah bahwa dari empat kepala bidang yang ada pada Dinas Pengelolaan Pendapatan, Keuangan dan Aset Daerah, hanya 50\% kepala bidang yang berlatar belakang pendidikan akuntansi atau manajemen keuangan; selebihnya dari disiplin ilmu lain.

Aspek penghambat lainnya adalah pejabat penatausahaan akuntansi keuangan pada SKPD rata-rata berlatar pendidikan non akuntansi atau manajemen keuangan. Hal ini menyebabkan tersendatnya berbagai aktivitas penatausahaan keuangan karena butuh waktu bagi mereka yang tidak berlatar belakang pendidikan akuntansi atau manajemen keuangan. Hal ini diperparah lagi dengan belum dilaksanakannya pelatihan akuntansi dan pelaporan keuangan secara rutin kepada pejabat pengelola keuangan pada satuan kerja perangkat daerah (PPK-SKPD).

Sasaran kedua untuk mencapai tujuan bidang akuntansi dan pelaporan adalah tercapainya sistem informasi akuntansi dan manajemen yang terintegrasi. Hasil analisis menunjukkan bahwa capaian skor untuk sasaran ini sebesar $50.00 \%$. Rendahnya capaian ini karena laporan keuangan dan laporan kinerja belum dihasilkan dari satu sistem. Hal ini dapat ditelusuri di mana laporan keuangan biasanya dihasilkan dari laporan perhitungan APBD pada dinas pengelolaan pendapatan, keuangan dan aset daerah sedangkan laporan kinerja dihasilkan dari masing-masing SKPD yang ada di Kabupaten Flores Timur.

Sasaran ketiga dari bidang akuntansi dan pelaporan adalah seluruh transaksi dan saldo keuangan pemerintah daerah dicatat secara akurat dan tepat waktu. Hasil analisis menunjukkan bahwa capaian skor dari sasaran ini sebesar $66.70 \%$. Ada satu kelehaman pada pencapaian sasaran ini yaitu belum adanya neraca awal pada masing-masing SKPD. Selama ini neraca awal hanya ada pada Dinas Pengelola Pendapatan, Keuangan dan Aset Daerah. 
Sasaran keempat dari bidang akuntansi dan pelaporan adalah terdapat laporan keuangan dan informasi manajemen anggaran yang dapat diandalkan. Hasil analisis menunjukkan bahwa capaian skor untuk sasaran ini sebesar 50.00\%. Salah satu aspek yang belum dilaksanakan untuk mencapai sasaran ini adalah belum adanya manual akuntansi sebagai pedoman pelaksanaan akuntansi. Pedoman yang dipergunakan untuk melaksanakan kegiatan akuntansi selama ini didasarkan pada aturan-aturan atau teori atau perundangan yang ada, tanpa diterjemahkan dalam bentuk manual akuntansi sebagai pedoman pelaksanaan akuntansi.

\section{Bidang Pengawasan Internal}

Tujuan strategis bidang pengawasan intern adalah terselenggaranya pengelolaan keuangan daerah yang efektif, efisien, transparan dan akuntabel. Hasil analisis menunjukkan bahwa total skor bidang pengawasan intern di Kabupaten Flores Timur mencapai 56.30\% dan berada pada kategori baik. Pencapaian tujuan strategis tersebut ditelusuri melalui pencapaian beberapa sasaran. Ada tiga sasaran dalam pencapaian tujuan strategis bidang pengawasan intern yaitu pertama ditetapkan dan terpeliharanya fungsi internal audit yang efektif dan efisien. Hasil analisis menunjukkan bahwa capaian skor untuk sasaran ini adalah 62.50\%. Beberapa indikator yang belum tercapai dalam sasaran ini adalah bahwa badan inspektorat daerah belum memiliki staf lebih dari $50.00 \%$ yang berkualifikasi jabatan fungsional auditor. Hasil analisis menunjukkan bahwa badan inspektorat daerah Kabupaten Flores Timur hanya memiliki staf yang berkualifikasi jabatan fungsional auditor sebanyak $28.00 \%$ dari jumlah staf yang ada yaitu sebanyak 45 orang. Pada sisi lain, badan inspektorat daerah Kabupaten Flores Timur belum memiliki staf yang berlatar belakang akuntansi lebih dari 50.00\%. Hasil analisis menunjukkan bahwa staf yang memiliki latar belakang pendidikan akuntansi hanya $13.00 \%$ (enam orang) dari jumlah staf yang ada. Hasil diagnosis bidang pengawasan internal seperti tampak pada Tabel 9.

Tabel 9. Total Capaian Skor Bidang Pengawasan Intern di Kabupaten Flores Timur

\begin{tabular}{|c|c|c|c|}
\hline Outcomes & $\begin{array}{c}\text { Total } \\
\text { Achievable } \\
\text { Score }\end{array}$ & $\begin{array}{c}\text { Total } \\
\text { Achieved } \\
\text { Score }\end{array}$ & $\begin{array}{l}\text { Area } \\
\text { Grade }\end{array}$ \\
\hline $\begin{array}{l}\text { Ditetapkan dan terpeliharanya fungsi } \\
\text { internal audit yang efektif dan efisien }\end{array}$ & 8 & 5 & $62.5 \%$ \\
\hline $\begin{array}{l}\text { Standar dan Prosedur Audit Internal yang } \\
\text { Diaplikasikan Dapat Diterima }\end{array}$ & 6 & 2 & $33.3 \%$ \\
\hline $\begin{array}{l}\text { Temuan Audit Internal Ditindaklanjuti } \\
\text { dengan Segera }\end{array}$ & 2 & 2 & $100.0 \%$ \\
\hline TOTAL & 16 & 9 & $56.3 \%$ \\
\hline
\end{tabular}

Sumber: Pengolahan Data Lapangan, 2010

Sasaran yang sudah dilaksanakan dengan baik untuk mencapai tujuan strategis bidang pengawawan intern di Kabupaten Flores Timur adalah bahwa temuan audit internal ditindaklanjuti dengan segera oleh bupati. Sedangkan sasaran yang belum dicapai secara optimal adalah belum terlaksananya standar dan prosedur audit internal yang diaplikasikan dan dapat diterima. Hasil analisis menunjukkan bahwa capaian skor untuk sasaran ini sebesar 33.30\%. Rendahnya capaian 
skor untuk sasaran ini karena beberapa indikator yang belum dilaksanakan yaitu bahwa badan inspektoral daerah baru sebatas mengaudit kegiatan pemerintah daerah dan belum menyentuh kegiatan komersial. Selain itu, badan inspektorat daerah Kabupaten Flores Timur belum secara reguler menguji sistem pengendalian intern yang ada dan implementasinya. Aspek lain yang memberikan kontribusi terhadap rendahnya pencapaian sasaran ini adalah badan inspektoral daerah Kabupaten Flores Timur belum mengkaji ulang dan merevisi program dan prosedur audit secara reguler.

\section{Bidang Hutang dan Investasi Publik}

Tujuan strategis bidang hutang dan investasi daerah adalah ditetapkannya pengelolaan yang hati-hati atas pinjaman daerah, investasi daerah, serta kepemilikan dalam BUMD. Dari semua bidang yang dianalisis, bidang hutang dan investasi daerah mempunyai total skor tertinggi yaitu sebesar $77.80 \%$ atau berada pada kategori sangat baik. Hasil diagnosis bidang hutang dan investasi publik ditampilkan pada Tabel 10.

Tabel 10. Total Capaian Skor Bidang Hutang dan Investasi Publik di Kabupaten Flores Timur

\begin{tabular}{lccc}
\hline \multicolumn{1}{c}{ Outcomes } & $\begin{array}{c}\text { Total } \\
\text { Achievable } \\
\text { Score }\end{array}$ & $\begin{array}{c}\text { Total } \\
\text { Achieved } \\
\text { Score }\end{array}$ & $\begin{array}{c}\text { Area } \\
\text { Grade }\end{array}$ \\
$\begin{array}{l}\text { Kebijakan, Prosedur, serta Pengendalian } \\
\text { dan Pinjaman Investasi Daerah yang }\end{array}$ & 5 & 3 & $\mathbf{6 0 . 0 \%}$ \\
$\begin{array}{l}\text { Memperhitungkan Resiko Telah Ditetapkan } \\
\text { dan Dilaksanakan }\end{array}$ & & & \\
$\begin{array}{l}\text { Kebijakan, Prosedur dan Pengelolaan } \\
\begin{array}{l}\text { Penerimaan Hibah telah ditetapkan dan } \\
\text { dilaksanakan }\end{array}\end{array}$ & 4 & 4 & $\mathbf{1 0 0 . 0 \%}$ \\
TOTAL & $\mathbf{9}$ & $\mathbf{7}$ & $\mathbf{7 7 . 8 \%}$ \\
\hline
\end{tabular}

Sumber: Pengolahan Data Lapangan, 2010

Untuk mengetahui pencapaian tujuan strategis bidang hutang dan investasi publik daerah maka dapat ditelusuri melalui pencapaian sasaran-sasaran yang ditetapkan. Ada dua sasaran untuk mencapai tujuan strategis bidang hutang dan investasi. Sasaran pertama adalah telah ditetapkan dan dilaksanakan kebijakan, prosedur dan pengelolaan penerimaan hiba. Dalam pelaksanaan sasaran ini telah dicapai secara sempurna. Sasaran kedua adalah telah ditetapkan dan dilaksanakan kebijakan, prosedur, serta pengendalian dan pinjaman investasi daerah yang memperhitungkan resiko. Hasil analisis menunjukkan bahwa capaian skor untuk sasaran ini sebesar $60.00 \%$. Namun demikian, ada beberapa indikator yang perlu ditingkatkan pada masa yang akan datang, yaitu pertama: bahwa sampai dengan saat ini pemerintah daerah belum mempunyai pinjaman daerah dan dengan demikian maka belum dapat dikatakan bahwa kebijakan pengelolaan pinjaman daerah dilaksanakan sesuai dengan kerangka kebijakan nasional. Dalam keadaan tertentu pinjaman daerah adalah baik, dan oleh karenanya dianjurkan agar pemerintah daerah juga mulai memikirkan dan menerapkan pinjaman daerah guna mempercepat pembangunan di daerah. 
Kedua, sampai sejauh ini pemerintah daerah Kabupaten Flores Timur belum melaksanakan investasi daerah dalam jangka panjang. Oleh karenanya belum dapat dikatakan bahwa pemerintah daerah Flores Timur telah melaksanakan kebijakan pengelolaan investasi daerah sesuai kerangka kebijakan nasional. Ke depan diharapkan pemerintah daerah dapat menciptakan investasi jangka panjang guna mendorong pertumbuhan ekonomi daerah, memperluas kesempatan kerja, meningkatkan pendapatan masyarakat dan juga pada akhirnya meningkatkan PAD.

\section{Bidang Pengelolaan Aset}

Tujuan strategis bidang pengelolaan aset adalah peningkatan keefektifan pengelolaan aset daerah melalui perencanaan dan pengelolaan aset jangka panjang yang menjamin terciptanya layanan terbaik dalam mendukung kelancaran aktifitas pemerintahan. Hasil analisis menunjukkan bahwa total skor bidang pengelolaan aset sebesar $72.20 \%$ dan berada pada kategori sangat baik.

Tabel 11. Total Capaian Skor Bidang Pengelolaan Aset di Kabupaten Flores Timur

\begin{tabular}{|c|c|c|c|}
\hline Outcomes & $\begin{array}{c}\text { Total } \\
\text { Achievable } \\
\text { Score }\end{array}$ & $\begin{array}{c}\text { Total } \\
\text { Achieved } \\
\text { Score }\end{array}$ & $\begin{array}{c}\text { Area } \\
\text { Grade }\end{array}$ \\
\hline $\begin{array}{l}\text { Terdapat kebijakan yang mengatur } \\
\text { penggunaan dan pemanfaatan aset } \\
\text { daerah yang mendukung tertib } \\
\text { pengelolaan aset daerah }\end{array}$ & 5 & 4 & $80.0 \%$ \\
\hline $\begin{array}{l}\text { Kebijakan dan prosedur pemeliharaan } \\
\text { asset dilakukan dan terintegrasi } \\
\text { dengan proses perencanaan daerah } \\
\text { untuk memastikan kondisi aset selalu } \\
\text { siap digunakan }\end{array}$ & 3 & 1 & $33.3 \%$ \\
\hline $\begin{array}{l}\text { Terdapat kebijakan, sistem dan } \\
\text { prosedur pencatatan, perolehan, } \\
\text { penilaian, pemindahtangan dan } \\
\text { penghapusan dan pelaporan barang } \\
\text { daerah yang efektif }\end{array}$ & 10 & 8 & $80.0 \%$ \\
\hline TOTAL & 18 & 13 & $72.2 \%$ \\
\hline
\end{tabular}

Pencapaian tujuan bidang pengelolaan aset ditentukan oleh pencapaian tiga sasaran penting yaitu pertama, terdapat kebijakan yang mengatur penggunaan dan pemanfaatan aset daerah yang mendukung tertib pengelolaan aset daerah; sasaran kedua adalah terdapat kebijakan, sistem dan prosedur pencatatan, perolehan, penilaian, pemindahtangan dan penghapusan dan pelaporan barang daerah yang efektif; kedua sasaran ini telah dicapai secara baik dengan capaian skor masing-masing sebesar $80.00 \%$. 
Adapun sasaran ketiga adalah kebijakan dan prosedur pemeliharaan asset dilakukan dan terintegrasi dengan proses perencanaan daerah untuk memastikan kondisi aset selalu siap digunakan; capaian skor untuk sasaran ini sebesar 33.30\%. Beberapa indikator yang perlu diperbaiki pada masa yang akan datang adalah: bahwa laporan barang daerah yang disiapkan oleh pengelola barang daerah belum merupakan sumber utama pelaporan aset dalam neraca daerah; dan berikutnya adalah bahwa pencatatan barang daerah di Kabupaten Flores Timur belum menggunakan sistem informasi barang daerah (SIMBADA) berbasis komputer.

\section{Bidang Audit dan Pengawasan Eksternal}

Tujuan strategis bidang pengawasan eksternal adalah meningkatkan akuntabilitas pengelolaan keuangan melalui audit eksternal dan pengawasan yang efektif dan independen. Hasil analisis menunjukkan bahwa total capaian skor bidang audit dan pengawasan eksternal di Kabupaten Flores Timur sebesar $75.00 \%$ dan berada pada kategori sangat baik. Capaian total skor ini ditentukan oleh capaian skor masing-masing sasaran. Hasil diagnosis bidang pengawasan eksternal tampak pada Tabel 12.

Tabel 12. Total Capaian Skor Bidang Audit dan Pengawasan Eksternal di Kabupaten Flores Timur

\begin{tabular}{cccc}
\hline Outcomes & $\begin{array}{c}\text { Total } \\
\text { Achievable } \\
\text { Score }\end{array}$ & $\begin{array}{c}\text { Total } \\
\text { Achieved } \\
\text { Score }\end{array}$ & $\begin{array}{c}\text { Area } \\
\text { Grade }\end{array}$ \\
$\begin{array}{c}\text { Audit Eksternal Rutin Menjamin Efektivitas } \\
\text { dan Akuntabilitas Pemerintah Daerah }\end{array}$ & 5 & 3 & $\mathbf{6 0 . 0 \%}$ \\
$\begin{array}{c}\text { Adanya fungsi pengawasan yang efektif } \\
\text { terhadap manajemen keuangan daerah } \\
\text { TOTAL }\end{array}$ & 3 & 3 & $\mathbf{1 0 0 . 0 \%}$ \\
\hline
\end{tabular}

Sumber: Pengolahan Data Lapangan, 2010

Ada dua sasaran dalam bidang audit dan pengawasan eksternal, yaitu Adanya fungsi pengawasan yang efektif terhadap manajemen keuangan daerah di mana fungsi ini telah dilaksanakan secara baik dengan capaian skor sebesar $100.00 \%$. Sedangkan fungsi lainnya adalah audit eksternal rutin menjamin efektivitas dan akuntabilitas pemerintah daerah di mana capaian skor untuk fungsi ini sebesar $60.00 \%$. Sampai dengan saat ini, Laporan Keuangan Pemda Kabupaten Flores Timur belum dipublikasikan baik melalui media massa setempat, pada papan pengumuman resmi atau melalui web site. Aspek lain yang belum dilaksanakan adalah bahwa masyarakat tidak menghadiri sidang DPRD yang mendiskusikan laporan pertanggungjawaban dan hasil audit BPK. Adapun alasan yang diberikan bahwa laporan pertanggungjawaban hanya melibatkan DPRD dengan pemerintah daerah; sementara hasil audit BPK menyangkut nama baik orang sehingga tidak patut dihadiri oleh masyarakat umum. 


\section{Perbandingan Hasil Temuan di Flores Timur dengan Temuan di Provinsi NTT}

Secara keseluruhan, temuan penelitian tentang pengelolaan keuangan publik di Kabupaten Flores Timur lebih baik dari pada temuan yang sama pada tingkat Provinsi NTT. Di Kabupaten Flores Timur pengelolaan keuangan publik dikategorikan sangat baik dengan skor $67 \%$ sementara temuan yang sama pada tingkat Provinsi NTT dikategorikan baik dengan skor 50\%. Di Kabupaten Flores Timur bidang pengelolaan keuangan publik dengan skor tertinggi adalah bidang hutang dan investasi pubik (78\%) sementara di tingkat Provinsi NTT bidang pengelolaan keuangan publik dengan skor tertinggi adalah bidang pengadaan (65\%). Pada sisi lain, pengelolaan keuangan publik bidang akuntansi dan pelaporan mendapatkan skor terendah baik pada tingkat Kabupaten Flores Timur maupun pada tingkat Provinsi NTT. Pengelolaan keuangan publik pada bidang akuntansi dan pelaporan di Kabupaten Flores Timur mempunyai skor 31\% maka di tingkat Provinsi NTT hanya $27 \%$ dan masing-masing berada pada kategori sedang/moderat.

Hasil temuan menunjukkan bahwa pengelolaan keuangan publik pada bidang kerangka peraturan perundangan daerah di Kabupaten Flores Timur dan di Provinsi NTT berada pada kategori sangat baik; perbedaannya bahwa skor untuk bidang tersebut di Provinsi NTT lebih tinggi (64\%) dari pada di Flores Timur (63\%). Pengelolaan keuangan publik pada bidang perencanaan dan penganggaran di Kabupaten Flores Timur berada pada kategori sangat baik (71\%) sementara di Provinsi NTT berada pada kategori baik (50\%); untuk bidang pengelolaan kas, di Kabupaten Flores Timur tergolong sangat baik (69\%) sedangkan di Provinsi NTT tergolong baik $(46 \%)$.

Hasil temuan lainnya adalah bahwa pengelolaan keuangan publik pada bidang pengadaan baik di Flores Timur maupun di Provinsi NTT berada pada kategori sangat baik, perbedaannya bahwa skor untuk bidang tersebut di Kabupaten Flores Timur lebih tinggi (71\%) dari pada di Provinsi NTT (65\%); sedangkan pengelolaan keuangan publik pada bidang pengawasan intern berada pada kategori sangat baik (60\%) sementara di Flores Timur berada pada kategori baik (56\%). Pengelolaan keuangan publik pada bidang investasi publik di Flores Timur dan Provinsi NTT cukup menyolok, dimana di Flores Timur sangat baik (78\%) sementara di Provinsi NTT berada pada kategori sedang/moderat (33\%).

Pengelolaan keuangan publik pada bidang pengelolaan aset serta bidang audit dan pengawasan eksternal di Kabupaten Flores Timur masing-masing berada pada kategori sangat baik (72\% dan 75\%), sementara di Provinsi NTT kedua bidang tersebut berada pada kategori baik (44\% dan 50\%).

\section{KESIMPULAN}

Secara keseluruhan, dapat disimpulkan bahwa pengelolaan keuangan publik di Kabupaten Flores Timur dikategorikan sangat baik. Hal ini dapat dilihat dari total capaian skor kesembilan bidang yang dianalisis yang mencapai $66.70 \%$. Namun demikian ada bidang yang perolehan skornya di atas $66.70 \%$ tetapi dibawah $80 \%$ dan ada pula capaian skor bidang tertentu di bawah $66.70 \%$ tetapi di atas $30 \%$. Dengan demikian tidak ada bidang yang memperoleh skor sempurna/excellent (80\%-100\%) dan tidak ada pula bidang yang memperoleh skor poor/not accepteble (0-19\%). Beberapa hal yang perlu direkomendasikan adalah: 
1. Dalam bidang kerangka peraturan perundangan daerah maka direkomendasikan segera dibuat kerangka peraturan perundangan daerah mengenai transparansi dan partisipasi masyarakat. Selain itu diperlukan disiplin penetapan peraturan perundangan daerah mengenai APBD yang tepat waktu yaitu sebelum tanggal 1 Januari tiap tahun anggaran. Perlu segera dibentuk peraturan kepala daerah tentang kebijakan akuntansi pemerintah daerah; peraturan perundangan daerah mengenai penanaman modal daerah; dan peraturan perundangan daerah tentang badan layanan umum daerah (BLUD).

2. Beberapa aspek yang perlu dilaksanakan dalam bidang perencanaan dan penganggaran adalah: perlu dibentuk dan dilaksanakan sistem pemantauan dan evaluasi partisipatif yang komprehensip dalam proses perencanaan dan penganggaran; diperlukan proses evaluasi atas RKA-SKPD dalam hal kesesuaian dengan KUA dan PPAS; diciptakan berbagai kemudahan sehingga masyarakat dapat dengan mudah mengakses dokumen perencanaan dan penganggaran. Selain itu, masyarakat perlu dilibatkan dalam pemantauan dan evaluasi kegiatan yang dilaksanakan oleh SKPD. Selama ini proses perencanaan dan penganggaran telah mencakup komponen partisipatif, yang ditunjukkan dengan keterlibatan masyarakat dalam berbagai tingkatan musrenbangda, kendati belum ada aturan tentang partisipasi masyarakat.

3. Dalam bidang pengelolaan kas diperlukan sistem penagihan dan pemungutan pendapatan daerah secara efisien; diperlukan kehati-hatian dalam membuat rancangan peraturan mengenai pajak dan retribusi daerah sehingga tidak ditolak oleh pemerintah; diperlukan sistem penagihan dan pemungutan yang terintegrasi disertai dengan tersedianya layanan untuk menanggapi pertanyaan para pembayar pajak; diperlukan sanksi tegas yang dikenakan kepada para penunggak utang pajak; sangat dianjurkan agar bagian keuangan melakukan rekonsiliasi harian terhadap rekening bank yang terkait dengan pendapatan.

4. Dalam bidang akuntansi dan pelaporan diperlukan reformasi total dalam hal ketenagaan dengan menempatkan semua kepala bidang dengan personil yang berlatar belakang pendidikan akuntansi. Perlu dengan segera ditempatkan pula pejabat penatausahaan akuntansi keuangan pada SKPD dengan personil yang berlatar belakang pendidikan akuntansi atau manajemen keuangan. Perlu dilaksanakan dengan segera pelatihan akuntansi dan pelaporan keuangan secara rutin kepada pejabat pengelola keuangan pada satuan kerja perangkat daerah (PPK-SKPD).

5. Beberapa indikator yang perlu diperbaiki pada bidang pengelolaan aset adalah: segera dibuatkan pencatatan barang daerah dengan menggunakan sistem informasi barang daerah (SIMBADA) berbasis komputer.

\section{DAFTAR PUSTAKA}

Abdul Halim, 2007, “Pengelolaan Keuangan Daerah, Edisi Kedua”, YKPN Yogyakarta. Ahmad Yani, 2002, Hubungan Keuangan antara Pemerintah Pusat dan Daerah di Indonesia, PT RajaGrafindo Persada, Jakarta. 
Kabupaten Flores Timur Dalam Angka 2009. BPS Kabupaten Flores Timur.

Mahmudi, 2009, “Manajemen Keuangan Daerah”, Erlangga, Jakarta.

Musgrave, R. A. and Musgrave, P. B., (1999). "Keuangan Negara dalam Teori dan Praktek", Erlangga, Jakarta.

Nurlan Darise, 2007, Pengelolaan Keuangan Pada Satuan Kerja Perangkat Daerah (SKPD), PT INDEKS.

Peraturan Menteri Nomor 13 Tahun 2006, yang diubah menjadi Peraturan Menteri Nomor 59 Tahun 2007 tentang Pengelolaan Keuangan Daerah. Jakarta

Peraturan Pemerintah Republik Indonesia Nomor 58 Tahun 2005, tentang Pengelolaan dan Pertanggung jawaban Keuangan Daerah, Jakarta.

Peraturan Menteri Dalam Negeri Nomor 13 Tahun 2006 tentang Pedoman Pengelolaan Keuangan Daerah

Republik Indonesia, Undang-Undang Nomor 33 Tahun 2004 Tentang Perimbangan Keuangan antara Pemerintah Pusat dan Pemerintah Daerah. 